\title{
Perception about BCG vaccination and tuberculosis among urban mothers
}

\author{
Rohit A.,"*, Chaya KA², Poornima MP', Balu PS ${ }^{4}$, Manu $\mathrm{AS}^{5}$ \\ ${ }^{1,2,3}$ Assistant Professor, ${ }^{4}$ Professor \& Head, ${ }^{5}$ Post Graduate, ${ }^{1,3,4,5}$ Dept. of Community Medicine, ${ }^{2}$ Dept. of Pediatrics, JJM \\ Medical College, Davanagere, Karnataka, India
}

*Corresponding Author:

Email: drrohita@gmail.com

\begin{abstract}
Aim: To identify perception about BCG vaccination and Tuberculosis awareness among urban mothers. Methodology: A cross sectional study was carried out among mothers residing in urban areas through health camps to know awareness about schedule of BCG vaccination, purpose of giving it and also find out awareness about Tuberculosis disease. Data was collected from August 2016 to January 2017 using a standard semi-structured questionnaire. Chi-square test was utilized to find the factors which are associated with students' knowledge about TB

Results: Among 241 study participants, main source of vaccine information was health department [n=127, 52.7\%] were aware of side effects of BCG vaccination [ $n=219,90.9 \%$ ]. All the participants had heard about Tuberculosis disease [ $n=241,100 \%]$, majority knew that it was a contagious [ $n=236,97.9 \%$ ] and mode of transmission $[n=199,82.6 \%]$.

Conclusion: Health workers continue to be main source of information for BCG vaccination and Tuberculosis. Awareness has to be improved regarding transmission of TB and prevention of TB meningitis through BCG vaccination.
\end{abstract}

Keywords: BCG, TB, Perception, Mothers, Vaccination.

\section{Introduction}

The Indian version of WHO's Expanded Programme on Immunization (EPI) to protect all children was launched on November 19, 1985 as Universal Immunization Programme. The National Health Policy aimed at achieving universal immunization coverage of the eligible population by $1990 .{ }^{1}$ Studies show that the immunization coverage is below the target level due to lack of awareness about immunization among the mothers. Despite efforts of the government and other health agencies, ${ }^{2}$ the coverage of all children under the universal immunization programme appears to be a distant dream and there is an urgent need to find the gaps that are preventing from achieving the desired targets of immunization., ${ }^{3,4}$ Awareness about disease and its immunization in both urban and rural mothers is needed in all scenarios. ${ }^{4,5}$

Tuberculosis (TB) continues to be one of the most important public health problems worldwide. Children are especially vulnerable to the effects of tuberculosis, which is often difficult to diagnose and therefore difficult to treat effectively. The compliance for treatment can be increased if caregivers of paediatric TB patients are well aware about the disease, treatment and preventive measures. ${ }^{6}$ Poor living conditions, malnutrition, shanty housing and overcrowding are the main reasons for the spread of the disease. Children are especially vulnerable to the effects of tuberculosis, which is often difficult to diagnose and therefore difficult to treat effectively. ${ }^{7,8} \mathrm{~TB}$ continues to be major health hazard and BCG vaccination coverage is important. ${ }^{7,9}$ BCG coverage is important indicator in TB control and mothers have an important role in it. ${ }^{10}$ Considering the situation, this study was done to identify perception about BCG vaccination and Tuberculosis awareness among urban mothers

\section{Materials and Methods}

A cross sectional study was carried out for a period of 6 months between March-August 2015 in Davanagere, a district headquarters in Central part of Karnataka state. 5 Camps were organised in urban areas of Davanagere with support from local women self help groups for benefit of people residing in different parts of city. Study subjects included women with children attending the camps

Inclusion criteria: All women having children less than 5 years and attending the health camp.

\section{Exclusion criteria:}

1. Women with history of tuberculosis

2. Consent not given

Study variables: Study subjects were assessed regarding their knowledge regarding BCG vaccination schedule, side effects, benefits and also about the Tuberculosis disease using pre tested, semi structured questionnaire

Sample size: A total of 241 subjects among the many people attending the camp and satisfying the study criteria were considered for the study.

\section{Statistical Analysis}

Data collected were entered using Epidata version 3.1 and analysed using IBMPSS 21.0.

\section{Result}

Among the 771 people who attended the 4 camps, 496 were females. Among 496 females, 241 were considered for the final study based on study criteria. Regarding general characteristics of participants 
majority belonged to Hindu religion [ $n=192,82.2 \%$, had nuclear family $[n=159,65 \%]$ and were housewife $[\mathrm{n}=197,81.7 \%]$. Literates were high in number and majority had one child $[n=147,61 \%]$. [Table 1].

Table 1: General characteristics of the study population

\begin{tabular}{|c|c|c|}
\hline Question & Number & Percentage \\
\hline \multicolumn{3}{|l|}{ Religion } \\
\hline Hindu & 198 & 82.2 \\
\hline ii. Muslim & 34 & 14.1 \\
\hline iii. Others & 9 & 3.7 \\
\hline \multicolumn{3}{|l|}{ Family Type } \\
\hline i. Joint & 159 & 65 \\
\hline ii. Nuclear & 82 & 35 \\
\hline \multicolumn{3}{|l|}{ Education status } \\
\hline i. Illiterate & 11 & 4.6 \\
\hline Upto Primary & 57 & 23.7 \\
\hline Upto secondary & 57 & 23.7 \\
\hline iv. Upto college & 69 & 28.6 \\
\hline v. Graduate and above & 47 & 19.4 \\
\hline \multicolumn{3}{|l|}{ Occupation } \\
\hline i. Housewife & 197 & 81.7 \\
\hline ii. Employed & 44 & 18.3 \\
\hline \multicolumn{3}{|l|}{ Parity } \\
\hline i. $\quad$ Primiparity[1] & 147 & 61 \\
\hline ii. Multiparity[2] & 77 & 32 \\
\hline iii. High multiparity[ 3 and more] & 17 & 7 \\
\hline
\end{tabular}

Regarding BCG vaccination, main source of information was from health department [n=127, 52.7\%] followed by relatives $[n=81,33.6]$ and media $[n=33,13.7 \%]$. Majority had immunization cards with them $[n=209,86.7 \%]$ and got vaccinated at government health facility $[\mathrm{n}=166,68.9]$. Most of the urban mothers were aware that BCG vaccination can have some side effects $[n=219,90.9 \%]$ and also result in scar formation $[n=221,92.1 \%]$ [Table 2]

Table 2: Awareness among Urban mother about BCG vaccination and scar formation

\begin{tabular}{|c|c|c|}
\hline \multicolumn{3}{|l|}{$\begin{array}{c}\text { Question } \\
\end{array}$} \\
\hline Main source of information & & \\
\hline Health worker/ Doctor & 127 & 52.7 \\
\hline ii. Family members/Relatives & 81 & 33.6 \\
\hline Media & 33 & 13.7 \\
\hline \multicolumn{3}{|l|}{ Immunization card } \\
\hline Present & 209 & 86.7 \\
\hline Absent & 32 & 13.3 \\
\hline \multicolumn{3}{|l|}{ Place of immunization } \\
\hline Govt & 166 & 68.9 \\
\hline Private & 75 & 31.1 \\
\hline \multicolumn{3}{|l|}{ BCG causes side effect } \\
\hline Yes & 219 & 90.9 \\
\hline No & 22 & 9.1 \\
\hline \multicolumn{3}{|l|}{ BCG results in scar formation } \\
\hline Yes & 221 & 92.1 \\
\hline ii. & 19 & 7.9 \\
\hline \multicolumn{3}{|l|}{ Eldest child's immunization status } \\
\hline i. Fully immunized & 217 & 90 \\
\hline ii. Partially immunized & 23 & 9.5 \\
\hline Unimmunized & 1 & 0.5 \\
\hline
\end{tabular}

All the participants had heard about Tuberculosis disease $[\mathrm{n}=241,100 \%]$ and their main source of information was health workers $[\mathrm{n}=151,62.7 \%]$ and majority knew that it was a contagious disease $[\mathrm{n}=236,97.9 \%]$ and were also aware about its mode of transmission $[n=199,82.6 \%]$. Many mothers did not knew if TB meningitis was 
preventable by vaccination $[\mathrm{n}=151,62.7 \%$ ] but were aware about major symptoms of the disease [n=187, 77.6\%], believed that TB is curable $[\mathrm{n}=238,98.8 \%]$ and had awareness regarding DOTS centre $[\mathrm{n}=210,87.1 \%]$ [Table 3]

Table 3: Awareness among Urban mothers about Tuberculosis disease

\begin{tabular}{|c|c|c|}
\hline Question & Number & Percentage \\
\hline $\begin{array}{l}\text { Heard about TB } \\
\text { i. Yes } \\
\text { ii. } \quad \text { No }\end{array}$ & $\begin{array}{l}241 \\
0\end{array}$ & $\begin{array}{l}100 \\
0\end{array}$ \\
\hline \begin{tabular}{ll}
\multicolumn{2}{l}{ Source of information } \\
i. & Health worker/ Doctor \\
ii. & Family members/Relatives \\
iii. & Media
\end{tabular} & $\begin{array}{l}151 \\
33 \\
57\end{array}$ & $\begin{array}{l}62.7 \\
13.7 \\
23.6\end{array}$ \\
\hline $\begin{array}{l}\text { TB is contagious disease } \\
\text { i. Yes } \\
\text { ii. No }\end{array}$ & $\begin{array}{l}236 \\
5\end{array}$ & $\begin{array}{l}97.9 \\
2.1\end{array}$ \\
\hline 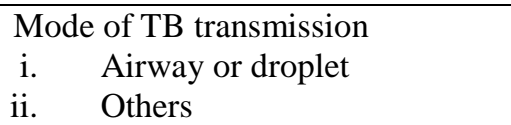 & $\begin{array}{l}199 \\
42\end{array}$ & $\begin{array}{l}82.6 \\
17.4\end{array}$ \\
\hline $\begin{array}{l}\text { Knowledge about Major symptoms } \\
\text { of TB } \\
\text { i. Yes } \\
\text { ii. } \quad \text { No }\end{array}$ & $\begin{array}{l}187 \\
54\end{array}$ & $\begin{array}{l}77.6 \\
22.4\end{array}$ \\
\hline $\begin{array}{l}\text { TB meningitis is preventable by } \\
\text { vaccination } \\
\text { i. Yes } \\
\text { ii. No } \\
\text { iii. Dont know }\end{array}$ & $\begin{array}{l}60 \\
30 \\
151\end{array}$ & $\begin{array}{l}24.9 \\
12.4 \\
62.7\end{array}$ \\
\hline $\begin{array}{l}\text { Knowledge regarding DOTS centre } \\
\text { i. Yes } \\
\text { ii. No }\end{array}$ & $\begin{array}{l}210 \\
31\end{array}$ & $\begin{array}{l}87.1 \\
12.9\end{array}$ \\
\hline $\begin{array}{l}\text { TB is curable } \\
\text { i. } \quad \text { Yes } \\
\text { ii. } \quad \text { No }\end{array}$ & $\begin{array}{l}238 \\
3 \\
\end{array}$ & $\begin{array}{l}98.8 \\
1.2\end{array}$ \\
\hline
\end{tabular}

\section{Discussion}

A Study done by Rohit A et al from Dharwad had shown that awareness about BCG was high among both Urban and Rural mothers. ${ }^{5}$ Main source of information regarding immunization was health workers and it is consistent with our study. ${ }^{5}$ Our study results are also consistent with study from Mangalore which found that knowledge about BCG vaccine and TB prevention, schedule of BCG and formation of papule after vaccination is high among Urban mothers. ${ }^{11}$ Rachna and Sheetal, found many of respondents (35\%) knew about Tuberculosis. ${ }^{12}$ and similar result was found about tuberculosis $(52.5 \%)$ by Sharma \& Bhasin. ${ }^{13}$ Research from Egypt has shown that nearly half of higher educated mothers gave their children their vaccinations at time and urban with moderate socioeconomic status had good total knowledge score about vaccination. ${ }^{14}$

Study from Belgrade has shown that Majoriy of study participants had knowledge that TB was a contagious disease and the mode of transmission. ${ }^{15}$ Relatives and friends, and to a lesser extent television, were the main sources of information about TB..$^{5,11,15}$
Similiar to our study, a study from south Indian found that majority considered $\mathrm{TB}$ as a serious disease. ${ }^{16}$ Regarding modes of spread, $65 \%$ were aware of cough as a mode of spread, About $16 \%$ were not aware of the free treatment for TB. ${ }^{16,17}$

Study results from Saria et al was consistent with our study findings where it was seen that patients awareness about transmission of disease and complete cure was better than previous times. But our results from Gujrat study showed that awareness regarding control and treatment of TB among care givers was matter of grave concern.

\section{Conclusion}

As number of literates are high in number majority of urban mothers are aware of side effects of BCG vaccination and also scar formation. Health workers continue to be main source of information regarding BCG vaccination and many get vaccinated at government health facility. All had heard about Tuberculosis disease and knew that it was a contagious disease. Many mothers did not knew if TB meningitis was preventable by vaccination but were aware about 
major symptoms of the disease. Awareness regarding mode of transmission was good and many believed that TB is curable and were aware about DOTS centre.

\section{Acknowledgement}

Department of Community Medicine and Department of Pediatrics for cooperation and women of local self help group for their support.

\section{References}

1. Jha Ranjit K Gopalakrishnan S Ajitha K Kuberan D Rana Manishkumar M Makade Kiran. Evaluation of Universal Immunization Programme in rural Tamil Nadu (Kancheepuram District). Indian Journal of Maternal and Child Health 2010; 12(3):1-9.

2. Thad Wilson. Factors Influencing the Immunization Status of Children in a Rural Setting. Journal of Pediatric Health Care 2000; 14(3):117-21.

3. V S Tapare, P S Borle. Assessment of Vaccination Performance by Lot Quality Technique in an Urban Community of Miraj. Indian Journal of Community Medicine 2006-07 - 2006-09;31(3)

4. M Chturvedi, Deoki Nandan, SC Gupta. Rapid assessment of immunization practices in Agra district. Indian Journal of Public Health 2007;51(2):132-4.

5. Rohit A, Patil PS, Dixit UR, Chowti JV. A Comparative Study on Awareness about Immunization in Urban-Rural Mothers. Indian Journal of Maternal and child health. Volume 16 (1), 2014.1-8.

6. Y Jani, GD Bhambhani, N Thakor. Knowledge and awareness of tuberculosis in caregivers of paediatric tuberculosis patients of north Gujarat region, India: a cross sectional study. International Journal of Research in Medical Sciences. 2015 Dec;3(12):3572-5.

7. Govt. of India (2013), TB India 2013, RNTCP Status Report, Central TB Division, Ministry of Health and Family Welfare, New Delhi. Available from: http://www.tbcindia.org Accessed 18 March 2018.

8. WHO, India Tuberculosis Profile, WHO report, 2013. Available from: http://www.who.int/tb/data Accessed 18 March 2018

9. Park K. Tuberculosis. In: Textbook of Preventive and Social Medicine, 24th edition, Jabalpur, Bhanot Publishers;2016

10. Loukia Aketi, JS Diayisu, Z Kashongwe, G Nkabikueni. Maternal Knowledge of Tuberculosis and Bacillus Calmette Guerin Vaccination in Pediatric Health Services in Kinshasa. Journal of Tuberculosis Research, 2017(5) 30-43. http://www.scirp.org/journal/jtr

11. Mereena, R Sujatha. A Study on Knowledge and Attitude Regarding Vaccines among Mothers of Under Five Children attending Pediatric OPD in a Selected Hospital at Mangalore. IOSR Journal of Nursing and Health Science. 2014 September. 3(5)39-46.

12. Rachna Kapoor, Sheetal Vyas. Awareness and knowledge of mothers of under five children regarding immunization in Ahmedabad. Healthline Journal, 2010 July- December (1);12-5.

13. Rahul Sharma, Sanjiv K Hasin. Routine ImmunizationDo People Know About It? A Study among Caretakers of Children attending Pulse Polio Immunization in East Delhi. Indian Journal of Community Medicine. 2008 January,33(1);31-4.

14. Sanaa M. Ahmed, Tarek A. Abd-El Rahman, Eman S Masoed. Mothers' awareness and knowledge of under five year's children regarding immunization in Minia city
Egypt. Life Science Journal 2013;10(4)1224-32 https://www.researchgate.net/profile/Tarek_Abdel_Rahman/publication/259186891_Mothers'_awareness_ and_knowledge_of_under_five_years_children_regarding _immunization_in_Minia_city_Egypt/links/00b4952a410 c5be07f000000/Mothers-awareness-and-knowledge-ofunder-five-years-children-regarding-immunization-inMinia-city-Egypt.pdf

15. Dejana S Vukovic, Ljudmila M Nagorni-Obradovic. Knowledge and awareness of tuberculosis among Roma population in Belgrade: a qualitative study. BMC Infect Dis. 2011 Oct 24;11:284. https://bmcinfectdis.biomedcentral.com/articles/10.1186/ 1471-2334-11-284

16. Palanivel Chinnakali, Jayalakshmy Ramakrishnan, Kavita Vasudevan, Jayanthi Gurumurthy, Ravi P, Upadhyay, Krishna C Panigrahi. Level of awareness about tuberculosis in urban slums: Implications for advocacy and communication strategy planning in the National program. 2013. Lung India 30(2);139-42. https://www.ncbi.nlm.nih.gov/pmc/articles/PMC3669554 I

17. MM Angadi, Arun Pulikkottil Jose, Rekha Udgiri, KA Masali, Vijaya Sorganvi. A Study of Knowledge, Attitude and Practices on Immunization of Children in Urban Slums of Bijapur City, Karnataka, India. Journal of Clinical and Diagnostic Research. 2013 Dec,7(12):28036. 